Barroso Chavez, whom Mr. Gonard had the opportunity of meeting in Mexico and also of welcoming to its headquarters when he visited Geneva in September.

It will retain good memories of Mr. MacAulay's chairmanship with him the institution's directorate always had the best of relations and he largely contributed to the League's constant development.

The new Chairman of the League's Board of Governors returned to Geneva after the Vienna Conference and honoured the ICRC with a further visit. ${ }^{1}$

\title{
LEAGUE ANNUAL REPORT
}

The League of Red Cross Societies has just issued its Annual Report for 1964. Clear and uncramped in layout, the 35 large size pages of this report are illustrated with fine photographs depicting the activities described in each chapter.

The contents include: Development Programme; Relief; Health and Social Service; Nursing; Junior Red Cross; Information and Publications; International Relations.

$M r$. Henrik Beer, Secretary-General, gives in the preface a summary of the main tasks which confronted the League in 1964. The main passages are quoted below:

The first year of the Red Cross movement's second century of existence was very different from 1963, when it celebrated the hundredth anniversary of its foundation. In 1964, hard facts took the place of tributes to its glorious history, events illustrating a hundred years' activities in the service of mankind, the countless proofs of confidence in its future inspired by this commemoration.

1 Plate: Mr. Barroso signing the ICRC's Gold Book. 


\section{IN THE RED CROSS WORLD}

True, it still felt the spur of the Centenary and important decisions of the Centenary Congress were implemented. But above all the League took cognizance of the role it can and should play in the vast sphere of activities open to the Red Cross in the world today. It faced the facts realistically, objectively, without veiling the difficulties inherent in limited resources.

One of the first tasks was to adapt its means to increasing demands from young, and less young Societies, in process of organisation or development. From the autumn of 1964, the League Red Cross Development Programme extended a network of delegates and technical experts over the whole world. Africa, Asia and Latin America were the main scenes of field work and appreciable material assistance in the form of instruction, information and relief.

New avenues also opened up for Health, Social Service, Nursing and Home Nursing, and Junior activities. The discussions at the Centenary Congress and the various international meetings which had taken place in connection with the Centenary celebrations started to bear fruit. National Societies which had not really known each other before established durable relations and valuable cooperation. This led to a series of international, and especially, regional gatherings during the year. Two regional Seminars were organised in Latin America, one at Lima, the other at Santiago de Chile, assembling all the Societies of this Continent. The South East Asian and Pacific Red Cross Forum in Australia proved as successful as its predecessor, the Founex International Centre.

Many new Societies are evolving. This redoubled efforts to draw up a first detailed Development Programme for the beginning of 1965, in application of the Board of Governors' Resolution (1963, No. 6). It was a thrilling achievement, conforming to the needs of the Societies concerned, but not without some danger from the financial angle...

Nevertheless, the League derived real satisfaction from this session of the Executive Committee. The large number of delegates in attendance and the excellent atmosphere of the discussions were a new proof of the Federation's interest in Red Cross affairs. 
Interesting, even bold suggestions were made at the meetings of the Advisory Committees preceding the Executive Committee's session. The Junior Red Cross Committee, for instance, requested the Secretariat to draw up a 5-year Junior Red Cross programme for incorporation in the League Development Programme.

Although there were fewer disasters in 1964, the League Relief Bureau nevertheless continued to carry out its " emergency centre" duties. It was also able to make a new detailed study of the League's role in the field of relief and in particular of the question of assistance to refugees.

In this connection the League this year terminated important relief actions such as those for the Rwanda refugees in the Congo (Kivu Province) and Tanzania or the Red Cross Feeding Programme for child victims of the Skopje earthquake.

Finally, disaster relief was the subject of an important debate of the United Nations Economic and Social Council, and U Thant, the Secretary General of the United Nations, again expressed his complete confidence in the League Relief Service.

The already close collaboration between the League and the United Nations and its specialized Agencies was still further developed this year, when International Co-operation Year and the Hunger, Disease and Illiteracy campaigns were in full development . . .

Local conflicts of a more or less serious nature broke out in 1964. These called for the never-failing presence of the Red Cross when man is stricken by misfortune in any shape of form. But in an era of progress, everyone must join also in establishing decent social, human and moral conditions for the underprivileged. It is urgent for the world to grasp and shoulder its responsibilities towards the hungry, the sick and illiterate.

With the support of its millions of members, the Red Cross will devote its energies to this twofold task. 